This item was submitted to Loughborough's Research Repository by the author.

Items in Figshare are protected by copyright, with all rights reserved, unless otherwise indicated.

\title{
A substitution-dependent light-up fluorescence probe for selectively detecting Fe3+ ions and its cell imaging application
}

PLEASE CITE THE PUBLISHED VERSION

https://doi.org/10.1002/adfm.201802833

PUBLISHER

(c) Wiley

VERSION

AM (Accepted Manuscript)

\section{PUBLISHER STATEMENT}

This work is made available according to the conditions of the Creative Commons Attribution-NonCommercialNoDerivatives 4.0 International (CC BY-NC-ND 4.0) licence. Full details of this licence are available at: https://creativecommons.org/licenses/by-nc-nd/4.0/

\section{LICENCE}

CC BY-NC-ND 4.0

\section{REPOSITORY RECORD}

Feng, Xing, Ying Li, Xuewen He, Haixiang Liu, Zheng Zhao, Ryan T. Kwok, Mark Elsegood, Jacky W.Y. Lam, and Ben Zhong Tang. 2018. "A Substitution-dependent Light-up Fluorescence Probe for Selectively Detecting Fe3+ lons and Its Cell Imaging Application”. Loughborough University. https://hdl.handle.net/2134/35176. 


\section{WILEY-VCH}

DOI: 10.1002/ ((please add manuscript number))

Article type: Full Paper

\section{A Substitution-dependant Light-up fluorescence probe for selectively detecting $\mathrm{Fe}^{3+}$ ions and its cell imaging application}

Xing Feng, Ying Li, Xuewen He, Haixiang Liu, Zheng Zhao, Ryan T. K. Kwok, Mark R. J. Elsegood, Jacky W. Y. Lam, Ben Zhong Tang*

((Optional Dedication))

Dr. X. Feng, Dr. Y. Li, Mr. X. He, Mr. H. Liu, Dr. Z. Zhao, Dr. R. T. K. Kwok, Dr. J. W. Y. Lam, Prof. B. Z. Tang

Division of Biomedical Engineering, Department of Chemistry, Hong Kong Branch of Chinese National Engineering Research Center for Tissue Restoration and Reconstruction, Institute for Advanced Study, Institute of Molecular Functional Materials, State Key Laboratory of Molecular Neuroscience, The Hong Kong University of Science and Technology (HKUST), Clear Water Bay, Kowloon, Hong Kong, China.

E-mail: tangbenz@ust.hk.

Dr. X. Feng

School of Materials and Energy, Guangdong University of Technology, Guangzhou 510006, P. R. China.

Dr. M. R. J. Elsegood

Chemistry Department, Loughborough University, Loughborough, LE11 3TU, UK

Prof. B. Z. Tang

NSFC Center for Luminescence from Molecular Aggregates, SCUT-HKUST Joint Research Laboratory, State Key Laboratory of Luminescent Materials and Devices, South China University of Technology, Guangzhou 510640, P.R. China.

Prof. B. Z. Tang

HKUST-Shenzhen Research Institute, No. 9 Yuexing 1st RD, South Area, Hi-tech Park, Nanshan, Shenzhen 518057, P.R. China.

Keywords: aggregation-induced emission, molecular recognition, iron (III), acid dissociation constant, cell imaging

Delibrate design of specific and sensitive molecular probes with distinctive physicial/chemical properties for analytes sensing is of great significance. Herein, by taking advantage of the position-dependent substituent effects, an aggregation induced emission (AIE) featured iron (III) probe from ortho-substituted pyridinyl-functionalized tetraphenylethylene (TPE-o-Py) was synthesized. It displayed high sensitivity and selectivity toward Iron (III) detection. The recognition arises from the position isomer of ortho-substitution, and the fact that TPE-o-Py has a low acid dissociation constant (pKa) that is close to that of hydrolyzed $\mathrm{Fe}^{3+}$. Importantly, TPE-o-Py as a light-up fluorescence probe 


\section{WILEY-VCH}

could be employed for iron (III) sensing in living cells with a pronounced red-shift in fluorescence color.

\section{Introduction}

Molecular recognition has attracted increasing attention because of its significant application in supramolecular chemistry and biological systems. ${ }^{[1]}$ The association of two molecules interacting by self-assembly or self-organization processes, can exhibit distinctive photophysical properties, biological activities, as well as visible molecular dynamics. ${ }^{[2]}$ However, optimizing molecular structure with appropriate affinity to achieve equilibration between sensitivity and selectivity for molecular recognition is still a great challenge.

Iron is an abundant and inexpensive metal, which has been widely used in the field of synthetic chemistry. ${ }^{[3]}$ It also plays an indispensable role for living organisms, such as haematopoiesis, enzyme production, metabolic energy conversion and immune function maintenance. ${ }^{[4 a]}$ An abnormal concentration of iron in living systems would harm their normal physiological function. ${ }^{[4]}$ Therefore, it is necessary to develop an efficient approach to monitor $\mathrm{Fe}^{3+}$ both in vivo and in vitro. ${ }^{[4 \mathrm{~b}, 5]}$ Comparing with the traditional strategies based on absorption colorimetry or electrochemical techniques, ${ }^{[6]}$ fluorescent $\mathrm{Fe}^{3+}$ probes showed advantages in higher sensitivity, faster responsiveness as well as greater practicability. In particular, a light-up type fluorescent probe offers a superiority in signal to noise ratio in target analyte recognition. Voelcker et al., presented a light-up fluorescent sensor based on graphene quantum dots for $\mathrm{Fe}^{3+}$ imaging in cancer stem cells, which showed high sensitivity with a detection limit of $0.02 \mu \mathrm{M}$. The proposed mechanism of this fluorescent sensor depended on the switching of the spirolactam ring of rhodamine between on and off states in the presence and absence of $\mathrm{Fe}^{3+}$, respectively. ${ }^{[7]}$ However, the design of reversible molecular conformation for the specific recognition of Iron (III) is still rare.

On the other hand, the aggregation-induced emission (AIE) luminogens show unique turn-on fluorescence characteristics. They exhibit non-emissive behaviour when dissolved in 


\section{WILEY-VCH}

good solvents but emit strong fluorescence in poor solvents by forming aggregates. ${ }^{[8]}$ The AIE phenomenon originates from the restriction of intramolecular rotations (RIR). ${ }^{[9]}$ The unique light-up AIE properties have been widely applied in subcellular/cellular imaging, long-lasting tracking of bioactivity, and imaging guided therapy. ${ }^{[10]}$ Our group previously demonstrated a 4-position pyridinyl-functionalized tetraphenylethylene AIEgen as a turn-on fluorescent probe for detection of trivalent cations, but it showed similar fluorescence responsiveness toward $\mathrm{Cr}^{3+}, \mathrm{Fe}^{3+}$, and $\mathrm{Al}^{3+}$ without obvious selectivity. ${ }^{[11]}$ In fact, although many AIE-active fluorescent probes had been reported for various cations/anions with special characteristics, there was little research focus on light-up type AIE probes for specific $\mathrm{Fe}^{3+}$ detection in live cells.

Depending on the substitution effect for electronic density contribution, we designed and synthesized an ortho-substituted pyridinyl-functionalized tetraphenylethylene molecule (TPE-o-Py), which possessed pronounced AIE characteristics with high sensitivity and selectivity in Iron (III) detection in a THF/water mixture. More interestingly, when the TPE-o-Py meets $\mathrm{Fe}^{3+}$ in living cells, the strong orange-red fluorescence could be observed though a fluorescence microscope, indicating a potential application for iron monitoring in living systems.

\section{Results and discussion}

\subsection{Synthesis}

The compound TPE-o-Py was synthesized by the Mizoroki-Heck coupling reaction as shown in Scheme 1. The target chemical structure was confirmed by ${ }^{1} \mathrm{H} /{ }^{13} \mathrm{C}$ NMR spectra, single crystal X-ray diffraction and high-resolution mass spectrometry, as well as elemental analysis.

\section{Insert Scheme 1 in here}

\subsection{Crystal structure}




\section{WILEY-VCH}

The single crystal of TPE-o-Py was grown by slow evaporation of a solution in a mixture of $\mathrm{CH}_{2} \mathrm{Cl}_{2}$ and hexane $(1: 1, \mathrm{vol} / \mathrm{vol})$. Single crystal X-ray diffraction analysis at $150 \mathrm{~K}$ revealed that TPE-o-Py crystallized in the monoclinic crystal system in space group I2/a. There are two molecules in the asymmetric unit (Figure 1). In the packing of the crystal structure, $\mathrm{C}-\mathrm{H} \cdots \pi$ intermolecular interactions dominate the contacts between neighbouring molecules. For example, the phenyl rings between neighboring molecules were associated together via several weak $\mathrm{C}-\mathrm{H} \cdots \pi$ interactions along the $c$ axis.

\section{Insert Figure 1 in here}

Generally, in TPE-based molecules, the four phenyl rings can rotate freely in solution or in the gas phase. This motion serves as a channel for the excited state to decay non-radiatively. However, in this case, due to the restricted rotation of the four peripheral phenyl moieties by $\mathrm{C}-\mathrm{H} \cdots \pi$ interactions between neighbouring molecules in the crystalline state, the $\mathrm{C}=\mathrm{C}$ bond of TPE can only undergo in-plane reorientations, named pedal motion. ${ }^{[13]}$ This inhibited rotation of the phenyl groups may have contributed to the static disorder observed in the structure. Both alkene groups are two-fold disordered in the first molecule, and the occupancy ratio of $\mathrm{C}(1) / \mathrm{C}(2): \mathrm{C}(1 \mathrm{X}) / \mathrm{C}(2 \mathrm{X}) \quad$ is $0.54: 0.46(2)$; the occupancy ratio of $\mathrm{C}(9) / \mathrm{C}(10): \mathrm{C}(9 \mathrm{X}) / \mathrm{C}(10 \mathrm{X})$ is $0.719: 0.218(16)$. Similarly, both alkene groups are two-fold disordered in the second molecule, and the occupancy ratio of $C(34) / C(35): C(34 X) / C(35 X)$ is 0.65:0.35(2); the occupancy ratio of $\mathrm{C}(42) / \mathrm{C}(43): \mathrm{C}(42 \mathrm{X}) / \mathrm{C}(43 \mathrm{X})$ is $0.637: 0.036(16)$. In this system, the single-crystal X-ray diffraction analysis offered a visible manifestation of the consequences of a restriction of intramolecular motion (RIM) dependent AIE mechanism ${ }^{[9]}$ at molecular level. One might imagine the molecules being unable to rotate freely during crystal growth and hence ending up disordered.

\subsection{Photophysical properties}

TPE-o-Py showed good solubility in various organic solvents, such as $\mathrm{CH}_{2} \mathrm{Cl}_{2}, \mathrm{CHCl}_{3}$, THF, and toluene, but aggregated in poor solvents (i.e. deionized water). Herein, the UV-vis 


\section{WILEY-VCH}

spectrum of TPE-o-Py was examined in tetrahydrofuran (THF) solution, and is shown in Figure S6. The compound exhibited a low energy absorption band at $348 \mathrm{~nm}$ with a molar absorption coefficient of $63734 \mathrm{~cm}^{-1} \mathrm{M}^{-1}$, corresponding to the absorption of $\pi-\pi^{*}$ transitions of the conjugated $\pi$-electron system in the TPE unit. Previous work indicated the position of the pyridyl nitrogen atom has a strong effect on the photophysical properties both in solution and the solid state. ${ }^{[14]}$ However, the location of the $\mathrm{N}$ atom at the 2-position or 4-position in TPE-Py system gives similar optical characteristics, so shows a limited effect on electron transitions. $^{[14 b]}$

\section{Insert Figure 2 in here}

To investigate the AIE characteristics in detail, different volume fractions of water $\left(f_{\mathrm{w}}\right)$ were added to the pure THF solutions of TPE-o-Py $(10 \mu \mathrm{M})$. Obviously, when $f_{\mathrm{w}}<70 \%$, TPE-o-Py emitted relatively weak FL signals with the maximum peak located at $472 \mathrm{~nm}$. However, after increasing above this point, the emission intensity enhanced dramatically, with about 10 -fold enhancement at $f_{\mathrm{w}}=90 \%$ compared with that in pure THF solution (Figure $2 \mathrm{~b}$ ), indicating its pronounced AIE property. ${ }^{[9]}$ Even in the solid state, this TPE-o-Py displayed strong sky-blue emission with a maximum at $486 \mathrm{~nm}$. The fluorescence quantum yields dramatically increased from 0.06 (in THF solution) to 0.58 (in the solid state).

\section{Insert Figure 3 in here}

The pyridine moiety is an excellent ligand which prefers to coordinate with transition and lanthanide metals in the periodic table; ${ }^{[15]}$ also, pyridine-containing fluorescent probes show considerable affiliation to metal cations both in vitro and vivo. ${ }^{[16]}$ Due to the $\mathrm{N}$ atom of pyridine being in the 2-position instead of the 4-position, the compound tended to form complexes more easily with lanthanide metals, by coordinating via the $\mathrm{N}$ atom and olefin moieties. ${ }^{[17]}$ However, after adding an amount of $\mathrm{Ir}^{3+}$ and $\mathrm{Ru}^{3+}$ to a mixture of $\mathrm{THF}-\mathrm{H}_{2} \mathrm{O}\left(f_{\mathrm{w}}=\right.$ 70\%) solution containing TPE-o-Py $(10 \mathrm{mM})$, no obvious fluorescence changes were observed. As with our previous application of isomer TPE-p-Py as a colorimetric and 


\section{WILEY-VCH}

ratiometric fluorescent probe to $\mathrm{Fe}^{3+}, \mathrm{Al}^{3+}$ and $\mathrm{Cr}^{3+},{ }^{[11]}$ herein ,we attempt to use TPE-o-Py as a "turn-on" fluorescence probe to detect trivalent cations $\left(\mathrm{Fe}^{3+}, \mathrm{Al}^{3+}\right.$, and $\left.\mathrm{Cr}^{3+}\right)$. As Figure 3 shows, there were no obvious changes in the fluorescence spectra of TPE-o-Py after mixing with various cations (such as $\mathrm{Na}^{+}, \mathrm{K}^{+}, \mathrm{Ca}^{2+}, \mathrm{Mg}^{2+}, \mathrm{Al}^{3+}, \mathrm{Cd}^{2+}, \mathrm{Co}^{2+}, \mathrm{Cr}^{2+}, \mathrm{Cu}^{2+}, \mathrm{Fe}^{2+}, \mathrm{Hg}^{2+}$, $\mathrm{Mn}^{2+}, \mathrm{Ni}^{2+}, \mathrm{Sr}^{2+}, \mathrm{Zn}^{2+}, \mathrm{Al}^{3+}$, and $\mathrm{Cr}^{3+}$, etc.) even at concentrations up to $10^{-5} \mathrm{M}$. Notably, only the response to $\mathrm{Fe}^{3+}$ was highly selective. It is noticeable that the fluorescence spectra of TPE-o-Py showed a gradual red-shift from $450 \mathrm{~nm}$ to $578 \mathrm{~nm}$ with increasing concentrations of $\mathrm{Fe}^{3+}$. These interesting results inspired us to deeply explore the inherent relationship between molecular conformation and coordination ability to the $\mathrm{Fe}^{3+}$ ion.

According to our report, ${ }^{[11]}$ the $\mathrm{M}^{3+}\left(\mathrm{Fe}^{3+}, \mathrm{Al}^{3+}\right.$, and $\left.\mathrm{Cr}^{3+}\right)$ was intensively hydrolyzed in water which leads to a protonated TPE-p-Py, which exhibits a red emission by an intramolecular charge transfer (ICT) effect. To prove this concept, the stability of TPE-o-Py in THF solution and at different $\mathrm{pH}$ values was investigated by UV-vis and PL spectra. As shown in Figure 4, the maximum absorption of TPE-o-Py was at $348 \mathrm{~nm}$ in pure THF. Also, the absorption profile presented slightly changes at different $\mathrm{pH}$ values (from 3.0 to 10.0). However, when $\mathrm{pH}<3.0$, the absorption spectra displayed a slight red-shift with decreased intensity. The absorption maximum was further shifted to $372 \mathrm{~nm}$ when $\mathrm{pH}=2.0$, indicating the TPE-o-Py could be protonated in the presence of strong acidic solution and leads to the intramolecular charge transfer (ICT) effect. More detailed information was observed in the PL spectrum. The PL spectrum of TPE-o-Py exhibits a broad peak at $472 \mathrm{~nm}$ when the $\mathrm{pH}$ value was higher than 3.0, and no change was observed except the emission intensity slightly decreased. However, when the $\mathrm{pH}<3.0$, a new peak appeared at $573 \mathrm{~nm}$ with the broad spectrum covering the whole visible range $(400-650 \mathrm{~nm})$. With the $\mathrm{pH}$ value progressivly decreasing to 1.0, the emission peak was further shifted to $595 \mathrm{~nm}$ with an increased emission intensity. Indeed, the $\mathrm{pH}$ value played a significant role in the absorption and emission profile of the TPE-o-Py molecule. 


\section{WILEY-VCH}

\section{Insert Figure 4 in here}

Further, we carefully examined the position isomer effect of the $\mathrm{N}$ atom for the acid dissociation constant $\left(\mathrm{pK}_{\mathrm{a}}\right)$ of TPE-o-Py. ${ }^{[18]}$ According to our calculations from emission intensity ratios versus $\mathrm{pH}$ value, the $\mathrm{pK}_{\mathrm{a}}$ value is 3.27 for TPE-o-Py. ${ }^{[19]}$ This suggested that the PL spectra would be changed greatly when the $\mathrm{pH}$ was lower than 3.27. Figure S7 illustrates the fluorescence titration experiments of TPE-o-Py with the $\mathrm{Fe}^{3+}$ in a mixture of THF- $\mathrm{H}_{2} \mathrm{O}\left(f_{\mathrm{w}}=70 \%\right)$ solution. Upon addition of $\mathrm{Fe}^{3+}$ to $2.0 \times 10^{-5} \mathrm{M}$, a remarkable red-shift of the emission maximum from $472 \mathrm{~nm}$ to $564 \mathrm{~nm}$ was observed. In addition, as the concentration of $\mathrm{Fe}^{3+}$ was increased, the PL intensity red fluorescence centered at $564 \mathrm{~nm}$ decreased with a slight red-shift from 564 to $573 \mathrm{~nm}$ due to the enhanced TICT effect. The PL spectra feature exhibited a slight red-shift before and after the addition of $\mathrm{Al}^{3+}$ (Figure 4c and Figure S8). In addition, the fluorescene probe can recognize $\mathrm{Fe}^{3+}$ with a considerable detection limit $\left(1.04 \times 10^{-5} \mathrm{M}\right)$. The $\mathrm{pK}_{\mathrm{a}}$ values of the metal ions were calculated and summarized in Table 1. Only the pKa (2.56) of $\mathrm{Fe}^{3+}$ was lower than that of TPE-o-Py (3.27). This is due to the hydrolyzation of $\mathrm{Fe}^{3+}$ in water and the ionized hydrogen protons that result from decreasing the $\mathrm{pH}$ of solution to lower than 3.27. On the other hand, owing to the nature of the different solubility products (Ksp) of the metal ions, it was difficult to decrease the $\mathrm{pH}$ to 3.27 and protonate TPE-o-Py in aqueous solution in the presence of $\mathrm{Al}^{3+}$ or $\mathrm{Cr}^{3+}$. In addition, because of the $\mathrm{pK}_{\mathrm{a}}$ of 5.62 and 4.98 for 4-Vinylpyridine and 2-Vinylpyridine, respectively, ${ }^{[18]}$ we could also infer that the pKa of TPE-p-Py was higher than that of TPE-o-Py, making it easy to protonate in hydrolyzing $\mathrm{M}^{3+}\left(\mathrm{Fe}^{3+}, \mathrm{Al}^{3+}\right.$, and $\left.\mathrm{Cr}^{3+}\right)$ solution.

To explore the proton effect for the electronic coupling of the TPE-o-Py molecule, the optimized molecular geometries in the ground-state of TPE-o-Py and $\mathrm{H}^{+} @$ TPE-o-Py were calculated by Gaussian 09W using the B3LYP/6-31G* basis set. ${ }^{[20]}$ In TPE-o-Py and $\mathrm{H}^{+} @ \mathrm{TPE}-\mathrm{o}-\mathrm{Py}$, the olefin bridge caused planarization of the $\pi$-system (torsion angle $<2.1^{0}$ ) between the pyridine ring within the TPE fragment. As a result, the HOMO of TPE-o-Py is 


\section{WILEY-VCH}

primarily located on the donor (i.e. pyridine moiety), and the LUMO is mostly delocalized on the TPE and partially on the extended $\pi$-conjugation. Whereas, in $\mathrm{H}^{+} @ \mathrm{TPE}-\mathrm{o}-\mathrm{Py}$, the HOMO is mainly spread over the whole molecule and the LUMO localized on the protonated pyridine moieties and $\mathrm{C}=\mathrm{C}$ bond. This result indicates that the $\mathrm{H}^{+} @ \mathrm{TPE}-\mathrm{o}-\mathrm{Py}$ underwent an ICT transition through an extending $\pi$-conjugation. Indeed, the HOMO-LUMO gap value of $\mathrm{H}^{+} @ \mathrm{TPE}-\mathrm{o}-\mathrm{Py}\left(\mathrm{E}_{\mathrm{g}}=1.69 \mathrm{eV}\right)$ was lower than that of TPE-o-Py $\left(\mathrm{E}_{\mathrm{g}}=3.43 \mathrm{eV}\right)$, leading to the red shift in absorption and emission spectra, which is in accord with our observations in the above experiments.

\subsection{Cell imaging}

Depending on the $\mathrm{pH}$ value effect, the high sensitivity and selectivity TPE-o-Py for detecting $\mathrm{Fe}^{3+}$ was then explored in vitro cellular imaging by confocal fluorescence microscopy. The HeLa and MCF-7 (breast cancer) cells were incubated with and without $\mathrm{Fe}^{3+}$ in medium for $2 \mathrm{~h}$ at $37{ }^{\circ} \mathrm{C}$, and then washed three times with PBS buffer $(\mathrm{pH}=7.4)$ to eliminate extra $\mathrm{Fe}^{3+}$. The treated living cells were re-incubated with TPE-o-Py $(10 \mu \mathrm{M})$ for $0.5 \mathrm{~h}$, before directly imaging under a confocal fluorescence microscope without further washing. In Figure 5 and Figure S10, the confocal section images of HeLa and MCF-7 cells exhibit normal morphology with good health. In the absence of $\mathrm{Fe}^{3+}$, the HeLa cells emitted deep blue fluorescence after being incubated with TPE-o-Py, while in the presence of $\mathrm{Fe}^{3+}$, blue and red fluorescence appeared simultaneously. As the concentration of $\mathrm{Fe}^{3+}$ was increased, the intensity of red fluorescence also enhanced, in agreement with the observation in THF/water. Further, the TPE-o-Py showed excellent biological compatibility even at $80 \mu \mathrm{m}$ concentration (Figure 6). The results revealed that TPE-o-Py could be potentially utilized as a biolabel to respond to $\mathrm{Fe}^{3+}$ both in HeLa and MCF-7 cells.

\section{Insert Figure 5 in here}

In addition, the cytotoxicity of TPE-o-Py was further evaluated using Calcein acetoxymethyl ester (AM)/propidium iodide (PI) assay (live/dead) kit and CCK8 assay. As 


\section{WILEY-VCH}

shown in Figure 6, The HeLa cells and MCF-7 cells exhibited green fluorescence at various concentrations of TPE-o-Py ranging from 0 to $80 \mu \mathrm{M}$. The cells distributed in radial or swirl patterns covering the plate surface and displayed normal cell morphology with spindle shapes, without dead cells appearing. The cell viability results showed that the viability of both cells remains close to $100 \%$ (> 95\%) over $24 \mathrm{~h}$ at a concentration of $80 \mu \mathrm{M}$, indicating the low cytotoxicity of TPE-o-Py.

\section{Insert Figure 6 in here}

\section{Conclusions}

A novel, ortho-substituted, pyridinyl-functionalized tetraphenylethylene TPE-o-Py was successfully synthesized via the Mizoroki-Heck coupling reaction. The AIE-active TPE-o-Py molecule exhibited weak emission in solution but strong fluorescence intensity in the aggregated state. Among various metal ions, only $\mathrm{Fe}^{3+}$ can induce the alteration in the fluorescence emission feature of TPE-o-Py from weak blue to strong red color. Furthermore, only the hydrolyzed $\mathrm{Fe}^{3+}$ can induce the protonation of TPE-o-Py, because of its lower acid dissociation constant $(\mathrm{pKa})$ which was close to that of hydrolyzed $\mathrm{Fe}^{3+}$. This is the first example of a TPE derived fluorescence probe possessing characteristics including $\mathrm{pH}$-dependence, turn-on capability, and ratiometric fluorescence for $\mathrm{Fe}^{3+}$ detection in live cells. The novel AIE-active TPE-o-Py is expected to be promising in the application of biological imaging and biomedical research in the future.

\section{Experimental Section}

General: ${ }^{1} \mathrm{H} /{ }^{13} \mathrm{C}$ NMR spectra (400 MHz) were recorded on a Mercury plus $400 \mathrm{MHz}$ NMR spectrometer respectively, and referenced to 7.26 and $77.0 \mathrm{ppm}$ for chloroform-D solvent with $\mathrm{SiMe}_{4}$ as an internal reference: $J$-values are given in $\mathrm{Hz}$. High-resolution mass spectra (HRMS) were taken on a GCT premier CAB048 mass spectrometer operating in a MALDI-TOF mode. Elemental analysis was performed on a ThermoFinnigan Flash EA1112 


\section{WILEY-VCH}

apparatus. FL spectra were recorded on a Hitachi 4500 spectrofluorometer. UV-vis absorption spectra were obtained on a Milton Ray Spectrofluorometer. Fluorescence quantum yields were measured using absolute methods. The quantum chemistry calculation was performed on the Gaussian 09W (B3LYP/6-31G* basis set) software package.

Crystallography: Crystallographic data for TPE-o-Py were collected on a Bruker APEX 2 CCD diffractometer with graphite-monochromated Mo K $\alpha$ radiation $(\lambda=0.71073 \AA)$ in the $\omega$-scan mode. Crystal data. $\mathrm{C}_{33} \mathrm{H}_{25} \mathrm{~N}, M=435.54$, monoclinic, $a=36.579(7), b=5.6069(11), c$ $=47.597(13) \AA, \beta=100.227(3)^{\circ}, U=9607(4) \AA^{3}, T=150(2) \mathrm{K}$, space group $I 2 / a, Z=16,1.7$ $\leq \theta \leq 22.5^{\circ}, 38508$ reflections measured, 6237 unique $\left(R_{\text {int }}=0.067\right)$, which were used in all calculations. The final $R=0.089$ (4561 observed data with $F^{2}>2 \sigma\left(F^{2}\right)$, wR( $\left.F^{2}\right)=0.212$ (all data) for 690 parameters, $S=1.04$. Largest difference electron density features within \pm 0.64 e $\AA^{-3}$. H atoms were constrained in a riding model. There are two molecules in the asymmetric unit. Both alkene groups were modelled as two-fold disordered in both molecules with restraints on anisotropic displacement parameters. The major component occupation factors at the following sites were as follows: at $\mathrm{C}(1) / \mathrm{C}(2)=54(2) \%$; at $\mathrm{C}(9) / \mathrm{C}(10)=71.9(16) \%$; at $\mathrm{C}(34) / \mathrm{C}(35)=65(2) \%$; at $\mathrm{C}(42) / \mathrm{C}(43)=63.7(16) \%$. The disorder arises because the space occupied by these or adjacent groups is similar in two different orientations. CCDC 1836698 contains the supplementary crystallographic data for this paper. These data can be obtained free of charge from The Cambridge Crystallographic Data Centre via www.ccdc.cam.ac.uk/data_request/cif.

Materials: Unless otherwise stated, all reagents used were purchased from J\&K Chemicals or Sigma-Aldrich and were used without further purification. The solvent tetrahydrofuran (THF) was distilled prior to use. The 1-(4-Bromophenyl)-1,2,2-triphenylethylene was prepared as described previously. ${ }^{[12]}$ The stock solutions of metal ions were prepared from $\mathrm{CdCl}_{2} \cdot 2.5 \mathrm{H}_{2} \mathrm{O}$, $\mathrm{CoCl}_{2} \cdot 6 \mathrm{H}_{2} \mathrm{O}, \quad \mathrm{CuSO}_{4}, \quad \mathrm{FeCl}_{3}, \quad \mathrm{HgCl}_{2}, \mathrm{LiCl}, \quad \mathrm{MgCl}_{2} \cdot 6 \mathrm{H}_{2} \mathrm{O}, \quad \mathrm{NiCl}_{2} \cdot 6 \mathrm{H}_{2} \mathrm{O}, \mathrm{Pb}\left(\mathrm{NO}_{3}\right)_{2}$, $\mathrm{Zn}\left(\mathrm{NO}_{3}\right)_{2} \cdot 7 \mathrm{H}_{2} \mathrm{O}, \mathrm{AgNO}_{3}, \mathrm{AlCl}_{3}, \mathrm{CrCl}_{3}, \mathrm{IrCl}_{3} \cdot \mathrm{xH}_{2} \mathrm{O}, \mathrm{KCl}, \mathrm{NaCl}$ and $\mathrm{NH}_{4} \mathrm{Cl}$ with doubly 


\section{WILEY-VCH}

distilled water. Dulbecco modified eagle medium (DMEM), fetal bovine serum (FBS),

penicillin $\mathrm{G}\left(100 \mathrm{U} \mathrm{mL}^{-1}\right)$, streptomycin $\left(100 \mathrm{U} \mathrm{mL}^{-1}\right)$, and $0.25 \%$ trypsin-0.53 mM EDTA solution were from Gibco (USA). HeLa cells and MCF-7 cells were from the Cell Bank of Peking Union Medical College (China). Calcein AM/ PI was from Dojindo (Japan).

Synthesis of compound (E)-2-(4-(1,2,2-triphenylvinyl)styryl) pyridine (TPE-o-Py): Into a 50 mL, two necked, round-bottom flask were added (2-(4-bromophenyl)ethene-1,1,2-triyl)tribenzene (495 mg, $1.2 \mathrm{mmol}, 1.0 \mathrm{eq}$ ), potassium phosphate (429 mg, $2 \mathrm{mmol}, 2 \mathrm{eq}$ ), palladium(II) acetate (14 mg, $0.06 \mathrm{mmol}, 0.05 \mathrm{eq}$ ). The flask was filled with nitrogen. Dimethylacetamide (3 mL) and 2-vinylpyridine (0.2 mL, 1.8 mmol, 1.5 eq) were injected to the flask. The mixture was warmed to $145{ }^{\circ} \mathrm{C}$ for $72 \mathrm{~h}$. After cooling to room temperature, the mixture was poured into $50 \mathrm{~mL}$ water and extracted with DCM $(50 \mathrm{~mL} \times 2)$. The collected organic layer was filtered and washed with brine twice, then dried over anhydrous magnesium sulfate. After solvent evaporation, the crude product was purified by silica-gel column chromatography using DCM/methanol (15:1 by volume) as eluent. A yellow solid of (E)-2-(4-(1,2,2-triphenylvinyl)styryl)pyridine (TPE-o-Py) was obtained. (320 mg, 61\%). ${ }^{1} \mathrm{H}$ NMR (400 MHz, $\mathrm{CDCl}_{3}$ ): $\delta_{\mathrm{H}}=7.01-7.12$ (m, 19H), 7.30-7.34 (m, 3H), 7.52 (d, $J=16.0 \mathrm{~Hz}, 1 \mathrm{H}), 7.63$ (t, 1H), 8.57 (d, $J=4.0 \mathrm{~Hz}, 1 \mathrm{H}) \mathrm{ppm} ;{ }^{13} \mathrm{C}$ NMR (100 $\left.\mathrm{MHz}, \mathrm{CDCl}_{3}\right): \delta_{\mathrm{C}}=155.07,149.03,143.36,143.05,143.01,142.94,140.69,139.90,135.86$, 134.02, 131.82, 131.11, 130.78, 130.72, 127.15, 127.09, 127.01, 125.95, 125.90, 125.83, 121.33, 121.30 ppm; HRMS (MALDI-TOF) (ESI): $\mathrm{m} / \mathrm{z}[\mathrm{M}+\mathrm{H}]^{+}$calcd for $\mathrm{C}_{33} \mathrm{H}_{25} \mathrm{~N}$ 435.1987 [ $\left.\mathrm{M}^{+}\right]$; found 436.2.

Cell fluorescence: HeLa cells and MCF-7 cells were incubated in DMEM medium supplemented with $10 \% \mathrm{FBS}$ at $37^{\circ} \mathrm{C}$ in a humidified atmosphere of $5 \% \mathrm{CO}_{2}$, which were seeded in confocal dishes $\left(10^{5}\right.$ cells/well $)$ in $2 \mathrm{~mL}$ culture medium. After incubation $24 \mathrm{~h}$, the cells were treated with $\mathrm{Fe}^{3+}$ solutions $(0 \mu \mathrm{M}, 25 \mu \mathrm{M}$ and $50 \mu \mathrm{M})$ for $2 \mathrm{~h}$ and washed 3 times with PBS buffer $(\mathrm{pH}=7.4)$ to remove any excess $\mathrm{Fe}^{3+}$. The treated HeLa cells and MCF-7 


\section{WILEY-VCH}

cells were then incubated with TPE-o-Py $(10 \mu \mathrm{M})$ in medium for $0.5 \mathrm{~h}$. Then the HeLa cells and MCF-7 cells were washed with PBS buffer 3 times, the cells were imaged by a confocal laser scanning microscope (CLSM) (LSM710, Carl Zeiss, Germany).

Cytotoxicity Assay of TPE-o-Py: Calcein AM/PI kit : Calcein AM/PI kit was used to analyze the cell viability and morphology of HeLa cells and MCF-7 cells cultured in medium (DMEM $+10 \%$ FBS $+1 \%$ PS) with different concentrations of TPE-o-Py $(0,5,10,20,40,80 \mu \mathrm{M})$. The cells $\left(1 \times 10^{5}\right.$ cells $\left.\mathrm{mL}^{-1}\right)$ were seeded in confocal dishes and incubated for $24 \mathrm{~h}\left(37^{\circ} \mathrm{C}\right.$, 5\% $\mathrm{CO}_{2}$ humidified atmosphere). The medium was removed, and then different concentrations of TPE-o-Py were added and the cells were incubated for another $24 \mathrm{~h}$. The culture medium was removed from the dishes and the cells were washed with PBS twice, 500 $\mu \mathrm{L}$ calcein AM/PI mixed solution was added into each well and the mixture was incubated for 20 min. Calcein AM/PI mixture was removed from the dish, the cells were washed with PBS once and $200 \mu \mathrm{L}$ PBS was added before observing by a CLSM.

CCK8 assay: HeLa cells and MCF-7 cells were cultured on 96-well plates $\left(1 \times 10^{4}\right.$ cells 200 $\mathrm{mL}^{-1}$ ) for $24 \mathrm{~h}$. The culture medium was removed and $200 \mu \mathrm{L}$ medium containing different concentrations of TPE-o-Py $(0,5,10,20,40,80 \mu \mathrm{M})$ was added and incubated for $24 \mathrm{~h}$. The culture medium was removed and $100 \mu \mathrm{L}$ CCK8 medium $(90 \mu \mathrm{L}$ medium and $10 \mu \mathrm{L}$ CCK8 solution) (Dojindo, Japan) was added into each well and the samples were incubated for $1 \mathrm{~h}$, then optical density (OD) of the samples was measured on a microplate reader (Tecan, infinite M200, Switzerland) at $450 \mathrm{~nm}$. The results were analyzed by OriginPro 8.0.

\section{Supporting Information}

Supporting Information is available from the Wiley Online Library or from the author.

\section{Acknowledgements}

X. Feng and Y. Li contributed equally to this work. This work was supported by the National Science Foundation of China (21602014, 21788102 and 51620105009), the Research Grants Council of Hong Kong (16305015, N_HKUST604/14), the Innovation and 


\section{WILEY-VCH}

Technology Commission (ITC-CNERC14SC01), the Science and Technology Plan of Shenzhen (JCYJ20160229205601482 and JCY20170818113602462)

Received: ((will be filled in by the editorial staff))

Revised: ((will be filled in by the editorial staff)) Published online: ((will be filled in by the editorial staff))

References

[1] a) X.-L. Ni, X. Zeng, C. Redshaw, T. Yamato, J. Org. Chem. 2011, 76, 5696; b) S. J. Barrow, S. Kasera, M. J. Rowland, J. d. Barrio, O. A. Scherman, Chem. Rev. 2015, 115, 12320; c) G. Yu, K. Jie, F. Huang, Chem. Rev. 2015, 115, 7240; d) M. W. Peczuh, A. D. Hamilton, Chem. Rev. 2000, 100, 2479; e) K. Ariga, H. Ito, J. P. Hill, H. Tsukube, Chem. Soc. Rev. 2012, 41, 5800.

[2] a) J. M. Abendroth, O. S. Bushuyev, P. S. Weiss, C. J. Barrett, ACS Nano 2015, 9, 7746; b) J. F. Stoddart, Acc. Chem. Res. 2001, 34, 410; c) M. A. Watson, S. L. Cockroft, Chem. Soc. Rev. 2016, 45, 6118.

[3] C. Bolm, J. Legros, J. L. Paih, L. Zani, Chem. Rev. 2004, 104, 6217.

[4] a) N. Abbaspour, R. Hurrell, R. Kelishadi, J Res Med Sci. 2014, 19, 164; b) K. N. Raymond, E. A. Dertz, S. S. Kim, Proc Natl Acad Sci USA. 2003, 100, 3584; c) K. Pantopoulos, S. K. Porwal, A. Tartakoff, L. Devireddy, Biochemistry 2012, 51, 5705.

[5] a) N. Narayanaswamy, T. Govindaraju, Sens. Actuators, B 2012, 161, 304; b) J. Zou, X. Wang, L. Zhang, J. Wang, Chem. Res. Toxicol. 2015, 28, 373.

[6] L. R. Kindra, C. J. Eggers, A. T. Liu, K. Mendoza, J. Mendoza, A. R. K. Myers, R. M. Penner, Anal. Chem. 2015, 87, 11492.

[7] R. Guo, S. Zhou, Y. Li, X. Li, L. Fan, N. H. Voelcker, ACS Appl. Mater. Interfaces 2015, 7, 23958. 


\section{WILEY-VCH}

[8] a) J. Mei, N. L. C. Leung, R. T. K. Kwok, J. W. Y. Lam, B. Z. Tang, Chem. Rev. 2015, 115, 11718; b) X. Lou, Y. Zhuang, X. Zuo, Y. Jia, Y. Hong, X. Min, Z. Zhang, X. Xu, N. Liu, F. Xia, B. Z. Tang, Anal. Chem. 2015, 87, 6822.

[9] a) J. Luo, Z. Xie, J. W. Y. Lam, L. Cheng, H. Chen, C. Qiu, H. S. Kwok, X. Zhan, Y. Liu, D. Zhu, B. Z. Tang, Chem. Commun. 2001, 1740; b) Y. Hong, J. W. Y. Lam, B. Z. Tang, Chem. Soc. Rev. 2011, 40, 5361; c) Y. Hong, J. W. Y. Lam, B. Z. Tang, Chem. Commun. 2009, 4332.

[10]a) H. Shi, R. T. K. Kwok, J. Liu, B. Xing, B. Z. Tang, B. Liu, J. Am. Chem. Soc. 2012, 134, 17972; b) M. Gao, B. Z. Tang, Drug Disscov. Today 2017, 22, 1288; c) C.

Gui, E. Zhao, R. T. K. Kwok, A. C. S. Leung, J. W. Y. Lam, M. Jiang, H. Deng, Y. Cai, W. Zhang, H. Su, B. Z. Tang, Chem. Sci. 2017, 8, 1822; d) Y. Yuan, B. Liu, Chem. Sci. 2017, 8, 2537; e) X. Gu, R. T. K. Kwok, J. W. Y. Lam, B. Z. Tang, Biomaterials 2017, 146, 115; f) Y. Cheng, J. Dai, C. Sun, R. Liu, T. Zhai, X. Lou, F. Xia, Angew. Chem. Int. Ed. 2018, 57, 3123.

[11]X. Chen, X. Yuan Shen, E. Guan, Y. Liu, A. Qin, J. Z. Sun, B. Z. Tang, Chem. Commun. 2013, 49, 1503.

[12]Z. Zhao, S. Chen, C. Y. K. Chan, J. W. Y. Lam, C. K.W. Jim, P. Lu, Z. Chang, H. S. Kwok, H. Qiu, B. Z. Tang, Chem. Asian J. 2012, 7, 484.

[13]a) J. Harada, K. Ogawa, Chem. Soc. Rev. 2009, 38, 2244; b) M. A. Kochman, A. Bil, C. A. Morrison, Phys. Chem. Chem. Phys. 2013, 15, 10803.

[14]a) R. Tang, X. Wang, W. Zhang, X. Zhuang, S. Bi, W. Zhang, F. Zhang, J. Mater. Chem. C 2016, 4, 7640; b) J. B. Pollock, T. R. Cook, G. L. Schneider, D. A. Lutterman, A. S. Davies, Peter J. Stang, Inorg. Chem. 2013, 52, 9254.

[15]a) J. M. Stauber, A. L. Wadler, C. E. Moore, A. L. Rheingold, J. S. Figueroa, Inorg. Chem. 2011, 50, 7309; b) C.-Y. Lin, J. C. Fettinger, P. P. Power, Inorg. Chem. 2017, 56, 


\section{WILEY-VCH}

9892-9902; c) S. Alvarez, Chem. Rev. 2015, 115, 13447; d) C.-G. Wang, Y.-H. Xing, Z.-P. Li, J. Li, X.-Q. Zeng, M.-F. Ge, S.-Y. Niu, Cryst. Growth Des. 2009, 9, 1525.

[16]a) S. Madhu, D. K. Sharma, S. K. Basu, S. Jadhav, A. Chowdhury, M. Ravikanth, Inorg. Chem. 2013, 52, 11136; b) N. Zhao, M. Li, Y. Yan, J. W. Y. Lam, Y. L. Zhang, Y. S. Zhao, K. S. Wong, B. Z. Tang, J. Mater. Chem. C 2013, 1, 4640; c) F. Miao, G. Song, Y. Sun, Y. Liu, F. Guo, W. Zhang, M. Tian, X. Yu, Biosens. Bioelectron. 2013, 50, 42.

[17]B. L. Small, Acc. Chem. Res. 2015, 48, 2599.

[18]a) R. J. Gillespie, E. A. Robinson, J Comput. Chem. 2006, 28, 87; b) M. O’Neil, Ed., The Merck Index, 14th Edition, Merck \& Co., Whitehouse Station, NJ, USA 2006; c) I. M. Kolthoff, P. J. Elving, F. H. Stross, Treatise on Analytical Chemistry, 2nd edition, Wiley-Interscience, Verlag GmbH \& Co. KGaA, Weinheim, 1993.

[19]A. M. Brown, Comput. Meth. Prog. Bio. 2001. 65, 191.

[20]M. J. Frisch, GAUSSIAN 09, revision C.01; Gaussian Inc.: Wallingford, CT, 2009. 


\section{WILEY-VCH}

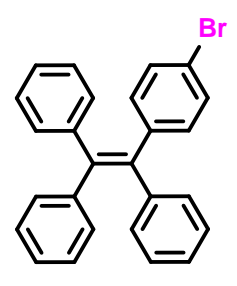

TPE-Br

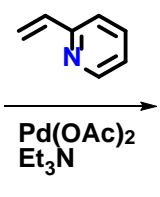

$\left.\mathrm{N}_{3} \mathrm{NAC}\right)_{2}$

(1)

TPE-o-Py<smiles>C(=C/c1ccccn1)\c1ccc(C(=C(c2ccccc2)c2ccccc2)c2ccccc2)cc1</smiles>

Scheme 1 the synthetic route to TPE-o-Py.

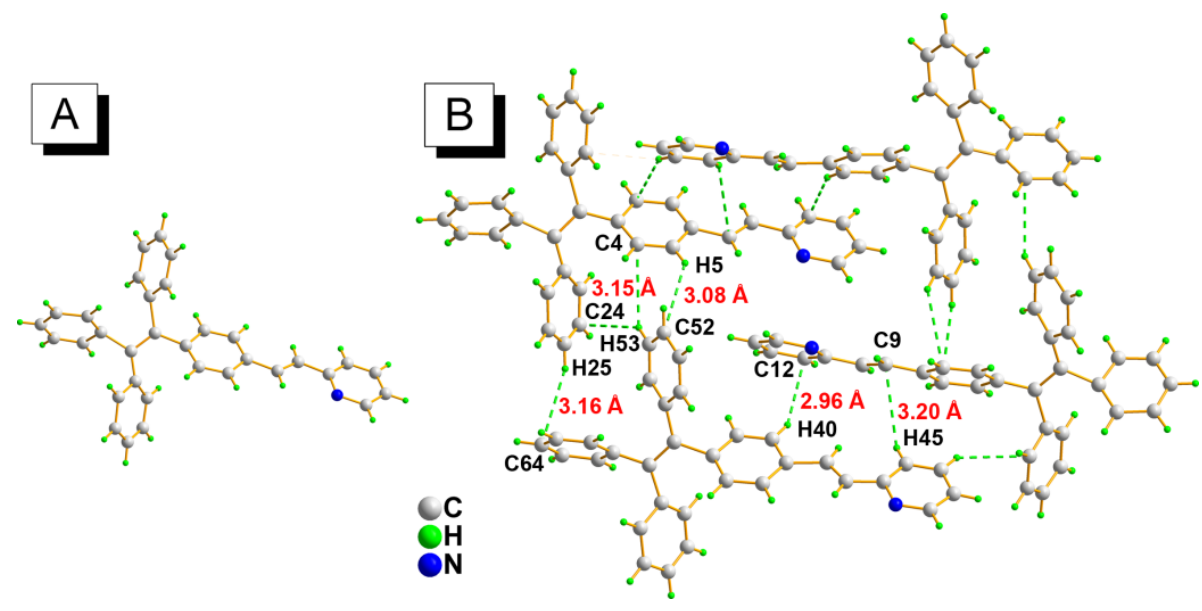

Figure 1 (left) Crystal structure of TPE-o-Py and (right) multiple C-H $\cdots \pi$ interactions between neighboring molecules. Minor disorder components have been omitted for clarity.
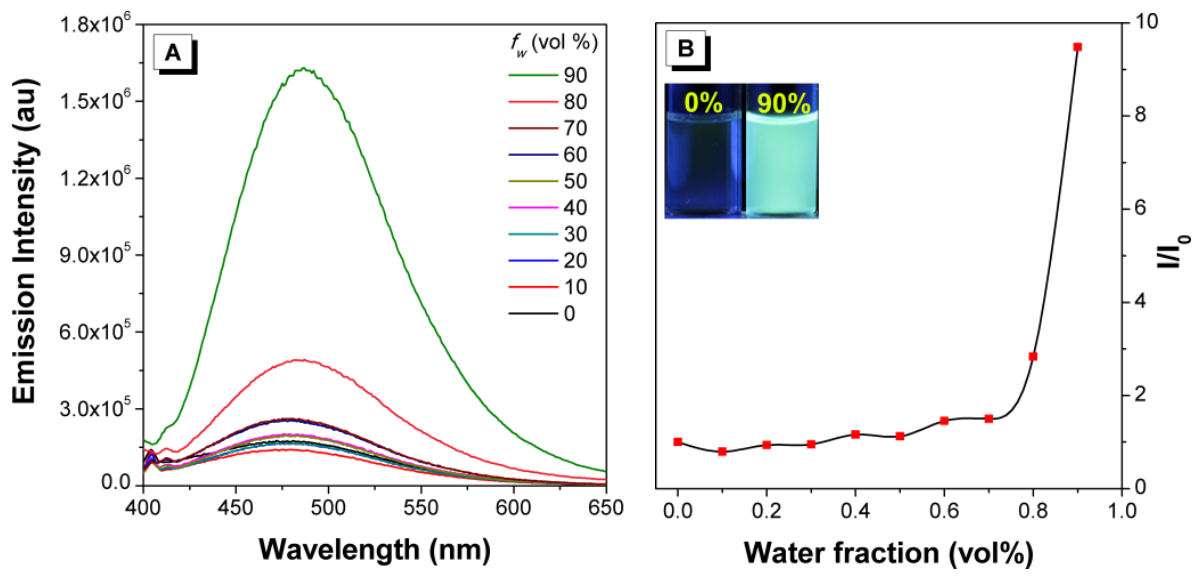

Figure 2 A) PL spectra of TPE-o-Py in THF/water mixtures with different water fractions. B) Plots of $\mathbf{I} / \mathbf{I}_{\boldsymbol{0}}$ values versus the compositions of THF/water mixtures, in which $\boldsymbol{I}_{\boldsymbol{0}}$ is the PL intensity in pure THF solution. Inset: photographs in THF/water mixtures $\left(f_{\mathrm{w}}=90 \%\right)$ taken under 365 nm UV irradiation. 


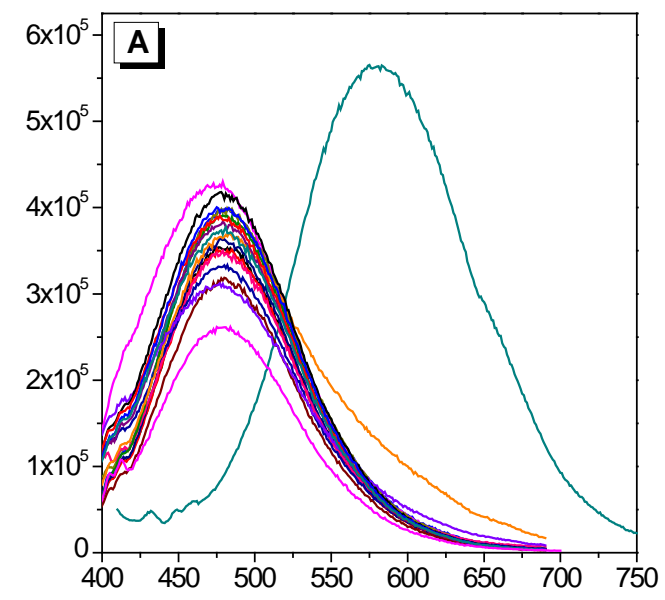

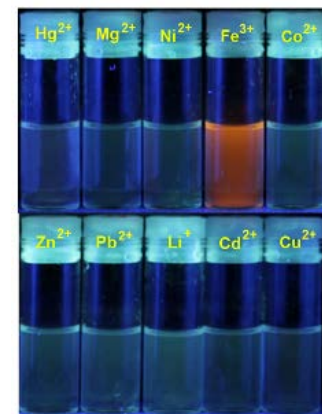

B]

Figure 3. (A) PL spectra of TPE-p-Py in THF and in THF/water mixture in the presence of $700 \mu \mathrm{M}$ of different metal cations. (B) Photographs of the above solutions taken under UV light $(\lambda \mathrm{ex}=365 \mathrm{~nm})$ and daylight, respectively. Concentration of [TPE-o-Py] $=10 \mu \mathrm{M}$.

[I don't understand the comment about the photographs, as I can only see one photograph of each solution, so how can there be both a photograph taken under UV light and one taken in daylight? ]
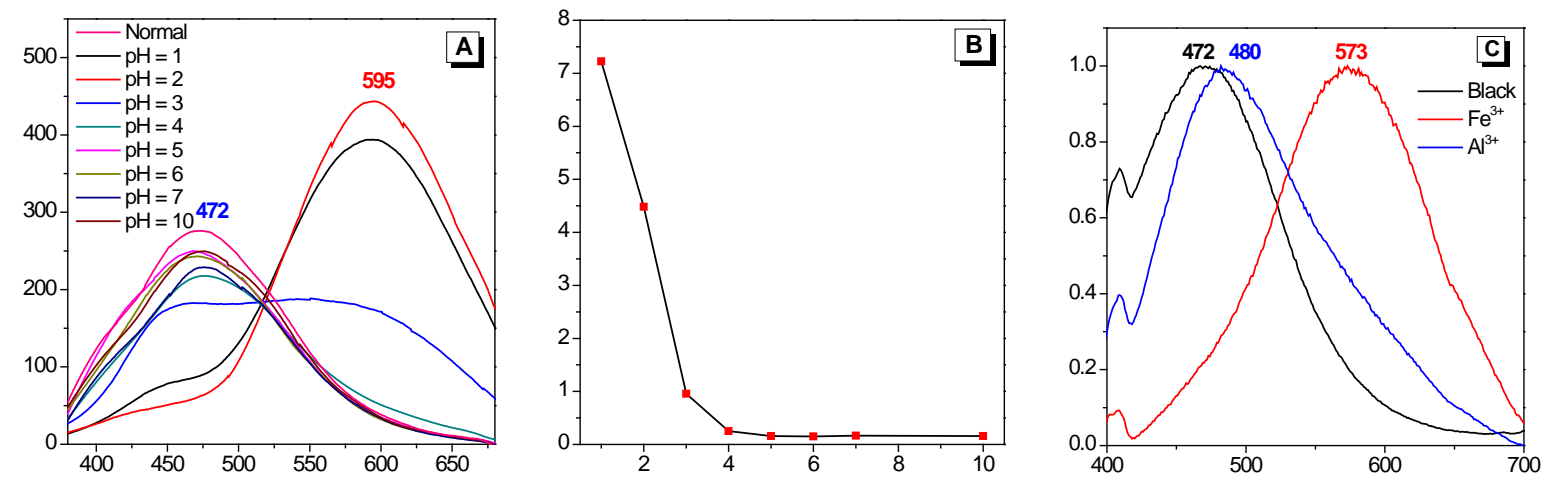

Figure 4. (A) PL spectra of TPE-o-Py $(10 \mu \mathrm{M})$ in different $\mathrm{pH}$ value buffers. (B) Plot of $\mathbf{I}_{595} / \mathbf{I}_{472}$ (ratio of intensity at $595 \mathrm{~nm}$ to intensity at $472 \mathrm{~nm}$ ) versus $\mathrm{pH}$ value, insert: photographs in different $\mathrm{pH}$ value $(\mathrm{pH}=1$ and $\mathrm{pH}=14)$ taken under $365 \mathrm{~nm}$ UV irradiation. (C) Normalization of PL spectra of TPE-o-Py $(10 \mu \mathrm{M})$ upon addition of $\mathrm{Fe}^{3+}$ and $\mathrm{Al}^{3+}(100$ $\mu \mathrm{M})$ in $\mathrm{THF} / \mathrm{H}_{2} \mathrm{O}\left(f_{\mathrm{w}}=70 \%\right)$ at $298 \mathrm{~K}(\lambda \mathrm{ex}=350 \mathrm{~nm})$. [There are no inserted photographs for $\mathrm{B}]$ 


\section{WILEY-VCH}
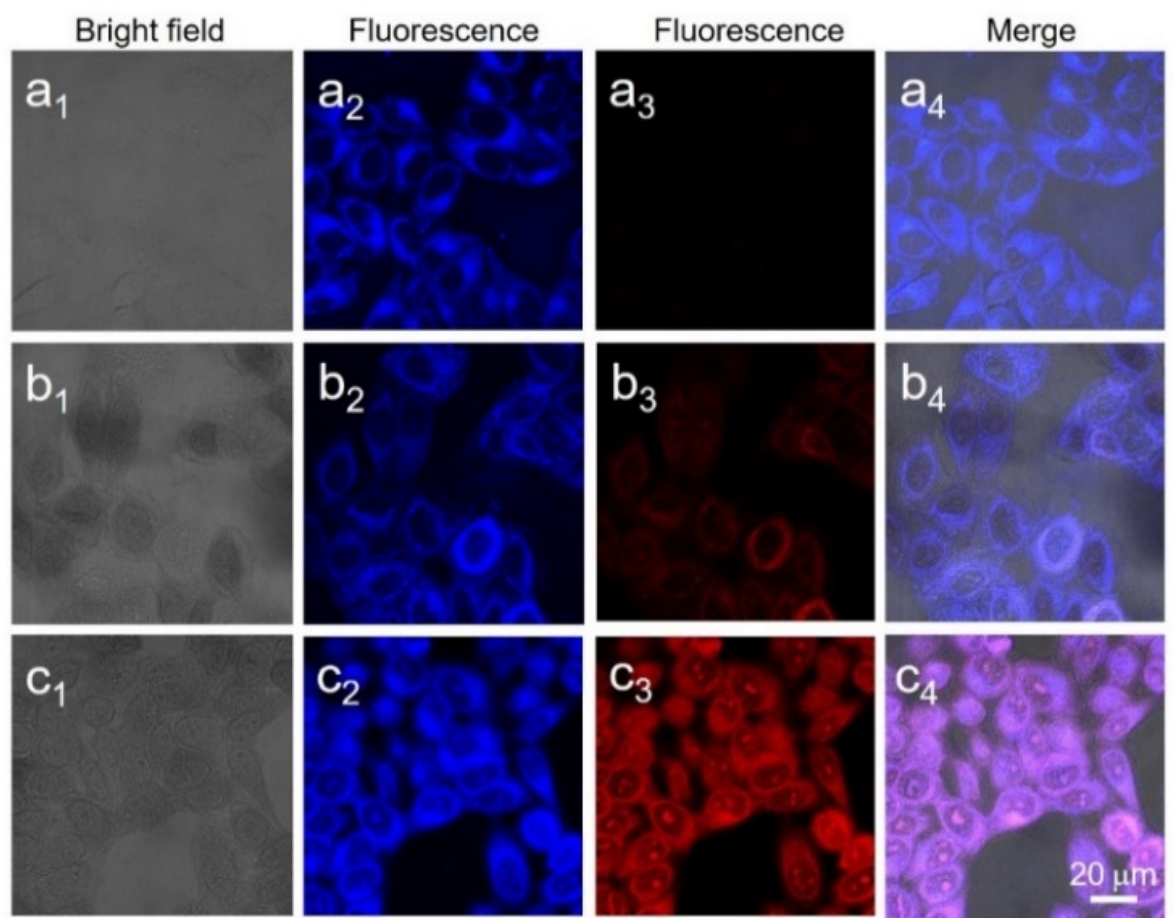

Figure 5. Confocal fluorescence microscopy images of HeLa cells incubated with $0 \mu \mathrm{M}(\mathrm{a})$, $25 \mu \mathrm{M}$ (b) and $50 \mu \mathrm{M}$ (c) $\mathrm{Fe}^{3+}$ for $2 \mathrm{~h}$, followed by further incubation with TPE-o-Py (10 $\left.\mu \mathrm{M}\right)$ for 0.5 h. The fluorescence was recorded under 440-480 $\mathrm{nm}\left(\mathrm{a}_{2}, \mathrm{~b}_{2}, \mathrm{c}_{2}\right)$ and 620-700 $\mathrm{nm}\left(\mathrm{a}_{3}, \mathrm{~b}_{3}\right.$, $\mathrm{c}_{3}$ ) emission wavelength (the scale bar is equal to $20 \mu \mathrm{m}$ ).
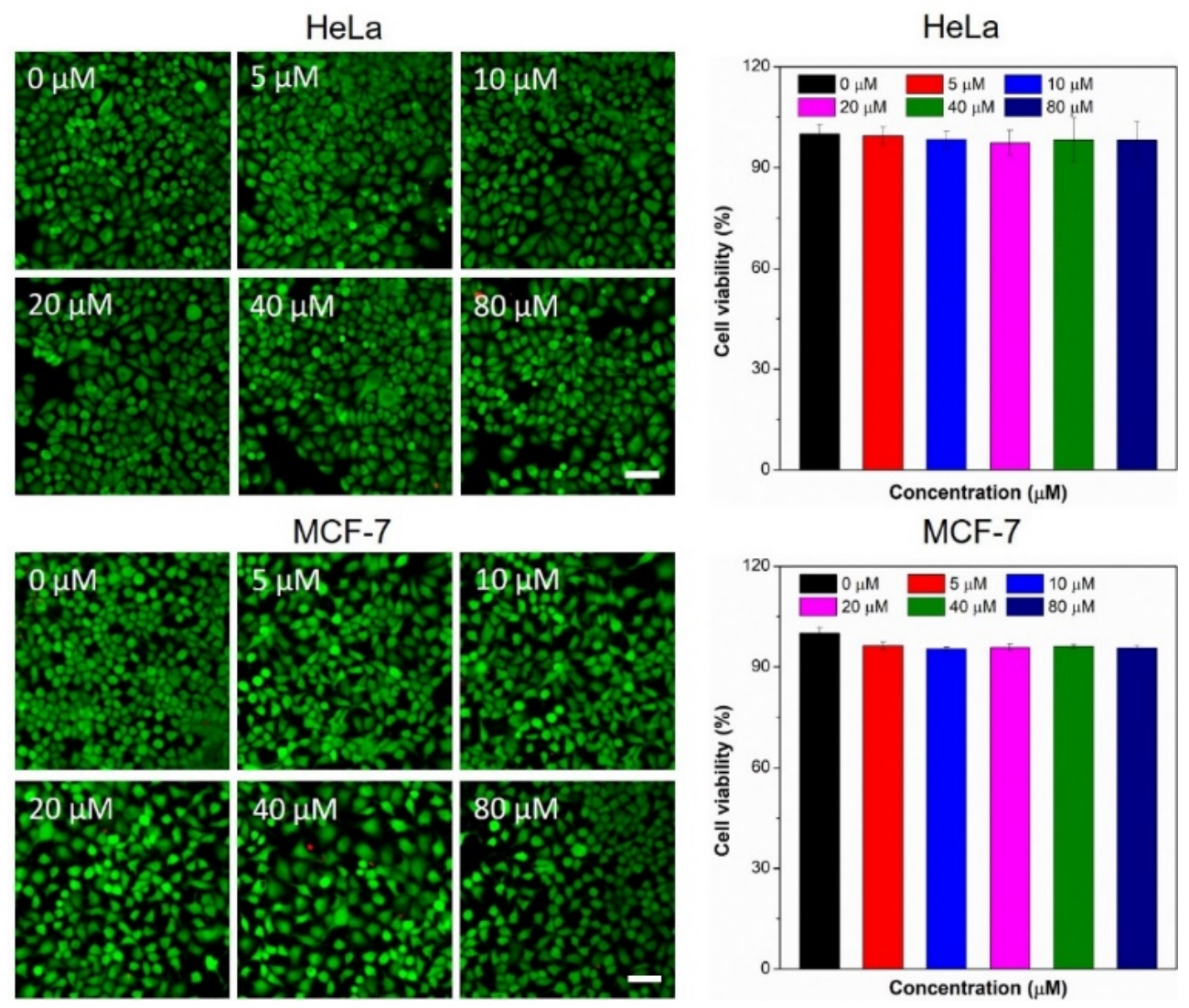

Figure 6 Fluorescence images of calcein AM/PI stained HeLa cells and MCF-7 cells (left panel) and CCK8 assay (right panel) of HeLa cells and MCF-7 cells treated by different 


\section{WILEY-VCH}

concentrations of TPE-o-Py. The scale bars equal to $100 \mu \mathrm{m}$, and the fields of vision (left panel) were randomly selected.

Table 1 The Ksp and pKa of differenct metal ions. ${ }^{[18]}$

\begin{tabular}{llllll}
\hline Metal ions & Ksp & pKa & Metal ions & Ksp & pKa \\
\hline $\mathrm{Fe}(\mathrm{OH})_{3}$ & $4 \times 10^{-38}$ & 2.56 & $\mathrm{Zn}(\mathrm{OH})_{2}$ & $1.2 \times 10^{-17}$ & 9.55 \\
$\mathrm{Al}(\mathrm{OH})_{3}$ & $1.3 \times 10^{-33}$ & 4.07 & $\mathrm{Cu}(\mathrm{OH})_{2}$ & $2.2 \times 10^{-20}$ & 8.64 \\
$\mathrm{Cr}(\mathrm{OH})_{3}$ & $6.3 \times 10^{-31}$ & 4.96 & $\mathrm{~Pb}(\mathrm{OH})_{2}$ & $1.2 \times 10^{-15}$ & 10.22 \\
$\mathrm{Fe}(\mathrm{OH})_{2}$ & $8.0 \times 10^{-16}$ & 10.16 & $\mathrm{Mg}(\mathrm{OH})_{2}$ & $1.8 \times 10^{-11}$ & 11.61 \\
$\mathrm{Co}(\mathrm{OH})_{2}$ & $1.6 \times 10^{-15}$ & 10.26 & $\mathrm{Ca}(\mathrm{OH})_{2}$ & $5.5 \times 10^{-6}$ & 13.44 \\
{$[\mathrm{TPE}-\mathrm{O}-\mathrm{Py}]=1 \times 10^{-5} \mathrm{M}$} & & & & \\
\hline
\end{tabular}




\section{WILEY-VCH}

The table of contents entry: The article presents an aggregation induced emission (AIE) featured iron (III) probe from ortho-substituted pyridinyl-functionalized tetraphenylethylene (TPE-o-Py) by taking advantage of the position-dependent substituent effects. It displayed high sensitivity and selectivity toward iron (III) detection. The molecular recognition mechanism arises from the position isomer of ortho-substitution of TPE-o-Py which has a low acid dissociation constant (pKa) that is close to that of hydrolyzed $\mathrm{Fe}^{3+}$. Importantly, TPE-o-Py as a light-up fluorescence probe could be employed for iron (III) sensing in living cells with a pronounced red-shift in fluorescence color.

Keyword: aggregation-induced emission, molecular recognition, iron (III), acid dissociation constant, cell imaging

Xing Feng, Ying Li, Xuewen He, Haixiang Liu, Zheng Zhao, Ryan T. K. Kwok, Mark R. J. Elsegood, Jacky W. Y. Lam, Ben Zhong Tang*

A Substitution-dependant Light-up fluorescence probe for selectively detecting $\mathrm{Fe}^{3+}$ ions and its cell imaging application

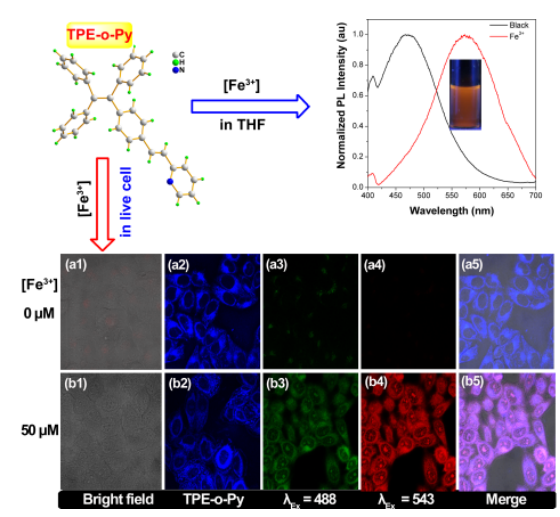

